\title{
Penerapan Regresi Nonparametrik Spline Dalam Memodelkan Faktor-Faktor Yang Mempengaruhi Indeks Pembangunan Manusia (IPM) di Indonesia Tahun 2018
}

\author{
Wahidah Alwi \\ Universitas Islam Negeri Alauddin Makassar,wahidah.alwi@uin-alauddin.ac.id \\ Muh. Irwan \\ Universitas Islam Negeri Alauddin Makassar,mirwan@uin-alauddin.ac.id \\ Musfirah \\ Universitas Islam Negeri Alauddin Makassar, musfirah.s,mat@gmail.com
}

\begin{abstract}
ABSTRAK, Penelitian ini membahas tentang faktorfaktor yang di duga mempengaruhi Indeks Pembangunan Manusia (IPM) di Indonesia, berdasarkan data dari Badan Pusat Statistik Indonesia pada tahun 2018. Beberapa faktor yang di duga mempengaruhi Indeks Pembanguanan Manusia (IPM) di Indonesia yaitu Tingkat Partisipasi Angkatan Kerja, Angka Partisipasi Murni, Kepadatan Penduduk, Fasilitas Kesehatan dan Produk Domestik Ragional Bruto (PDRB). Hasil plot Indeks Pembangunan Manusia (IPM) dengan faktor-faktor yang diduga mempengaruhi IPM memiliki pola yang menyebar, sehingga tidak memiliki kecenderungan membentuk suatu pola tertentu atau tidak mengikuti pola tertentu, sehingga data yang digunakan dapat diterapkan menggunakan metode Nonparametrik Spline. Dalam pemodelan ini terdapat tiga titik knot, pemilihan titik knot optimun dilakukan dengan cara memlilih nilai Generalized Cross Velidation $(G C V)$ yang paling minimum. Dari hasil peneilitian menunjukkan bahwa model Spline terbaik terbaik dengan GCV minimum berada pada tiga titik knot yaitu sebesar 0.2591359 dengan niai $R^{2}$ sebesar $84,79 \%$.
\end{abstract}

Kata Kunci: Indeks Pembangunan Manusia (IPM), GCV, Regresi Nonparametrik Spline, Titik Knot

\section{PENDAHULUAN}

Semakin lama perkembangan di Indonesia semakin pesat hal ini dapat dilihat dari teknologi yang saat ini sudah digunakan dimana-mana, tidak hanya teknologi sumber daya dan ilmu pengetahuan juga berekembang dengan pesat. Indeks Pembangunan Manusia (IPM) merupakan salah satu upaya bagaimana penduduk dapat mengakses hasil pembangunan dalam memperoleh pendapatan, kesehatan, pendidikan dan sebagainya. Indeks Pembangunan Manusia (IPM) pertama kali diperkenalkan oleh United Nations Development Programme (UNDP) pada tahun 1990 dan di publikasikan secara berkala dalam laporan tahunan Human Development Report (HDR). Pengetahuan, standar hidup layak, umur panjang dan hidup sehat merupakan dimensi dasar yang digunakan dalam pembentukan Indeks Pembangunan Manusia (IPM). Berdasarkan data Badan Pusat Statistik (BPS) diketahui bahwa IPM saat ini mengalami di mana pada tahun 2017 IPM sebesar 70,81\% dan saat ini IPM mencapai 71,39\%. Angka ini meningkat sebesar $0,58 \%$ atau tumbuh sebesar 0,82\% di bandingkan pada tahun sebelumnya.[1]

Analisis Regresi merupakan salah satu metode statistika yang memberikan penjelasan tentang hubungan (model) antara satu peubah tanggapan (response variabel) dengan satu peubah penjelas (explanatory variables). Ada dua pendekatan untuk mengestimasi fungsi regresi yaitu pendekatan parametrik dan nonparametrik. Pendekatan parametrik merupakan pendekatan yang digunakan apabila bentuk hubungan antara variabel bebas dan variabel terikat diketahui bentuk kurva regresinya yang diasumsikan mengikuti pola tertentu.[2]

Sedangkan nonparametrik digunakan apabila pola hubungan antara variabel penjelas dan variabel respon tidak diketahui bentuk kurva regresinya. Salah satu Metode Nonparametrik yaitu Metode NonParametrik Spline dimana metode ini sangat cocok di gunakan hal ini di sebabkan karena Spline merupakan potongan polinomial tersegmen yang mempunyai sifat fleksibilitas maksudnya bisa menyesuaikan diri secara efektif terhadap karakteristik suatu data.[3]

Dalam hal ini untuk memodelkan IPM dan beberapa variabel yang diduga berpengaruh, peneliti menggunkan metode regresi Nonparametrik Spline. Metode tersebut dipilih karena berdasarkan plot yang dihasilkan dengan pola hubungan antara variabel penjelas dan 
variabel respon memiliki pola yang menyebar, sehingga tidak memiliki kecenderungan membentuk suatu pola tertentu atau tidak mengikuti pola tertentu. Oleh karena itu dengan pola yang dihasilkan sulit digunakan pemodelan dengan pendekatan perametrik maka pola data yang dihasilkan akan dilanjutkan dengan menggunakan pendekatan nonparametrik.

\section{TINJAUANPUSTAKA}

\section{Analisis Regresi}

Analisis regresi dealam statistika adalah salah satu metode untuk menentukan hubungan sebab akibat antara satu variabel dengan variabel yang lain. Secara umum model regresi dapat ditulis

$$
Y=\beta_{0}+\beta_{1} X+\varepsilon
$$

Dimana $Y$ dinamakan variabel dependen, variabel $X$ di namakan variabel independen, $\beta_{0}$ (beta nol) dan (beta satu) adalah parameterparameter yang nilainya tidak diketahui, dan $\varepsilon$ (epsilon adalah galt acak (random error).[4] Hal ini sejalan dengan apa yang dikemukakan oleh Sunyoto (2011), bahwa tujuan analisis regresi adalah untuk mengetahui ada tidaknya pengaruh signifikan antara satu atau lebih variabel bebas terhadap variabel terikatnya baik secara persial atau simultan.[5]

\section{Regresi Nonparametrik Spline}

Spline merupakan model polinom yang tersegment atau terpotong-potong yang mulus dan dapat menghasilkan fungsi regresi yang sesuai dengan data. mengestimasi Spline tergantung pada titik knot. Titik knot merupakan suatu titik perpaduan yang terjadi kerena perubahan pola perilaku dari suatu fungsi pada selang yang berbeda.[6]

Metode regresi nonparametrik spline memiliki fleksibilitas yang tinggi dimana data diharapkan mencari sendiri bentuk estimasi kurva regresinya tanpa dipengaruhi oleh subjektifitas peneliti. Secara umum model regresi nonparametrik dapat disajikan sebagai berikut:

$$
y_{i}=f\left(x_{j i}\right)+\varepsilon_{i} ; \quad i=1,2, \ldots, n
$$

Pada model regresi nonparametrik spline, kurva regresi dihampiri dengan merupakan kurva fungsi spline berorde $p$ dengan titik knot $K_{1}, K_{2}, \ldots, K_{r}$ yang dapat diberikan oleh persamaan.

$$
\begin{array}{r}
f\left(x_{j i}\right)=\sum_{h=0}^{p} \beta_{0} x_{j i}^{h}+ \\
\sum_{l=1}^{m} \beta_{j(p+l)}\left(x_{j i}-K_{l j}\right)_{+}^{p}
\end{array}
$$

Apabila persamaan (2.2) disubtitusi kedalam persamaan (2.3) maka akan diperoleh persamaan regresi nonparametrik spline sebagai berikut:

$$
y_{i}=\sum_{h=0}^{p} \beta_{0} x_{j i}^{h}+\sum_{l=1}^{m} \beta_{j(p+j)}\left(x_{j i}-K_{l j}\right)_{+}^{p}+\varepsilon_{i}
$$

dimana $i=1,2, \ldots$. fungsi $\left(x_{j i}-K_{l j}\right)$ merupakan fungsi truncated (potongan) yang diberikan oleh:

$$
\left(x_{j i}-K_{l j}\right)_{+}^{p}= \begin{cases}\left(x_{j i}+K_{l j}\right)^{p} & , x_{j i} \geq K_{l j} \\ 0 & , x_{j i}<K_{l j}\end{cases}
$$

Bentuk matematis dari fungsi spline pada persamaan (2.5), dapat dinyatakan bahwa spline adalah potongan-potongan polinomial yang berbeda digabungkan bersama titik knot $K_{1}, K_{2}, \ldots$, $K_{m l}$. Persamaan (2.5) dapat diuraikan sebagai berikut[7]:

$$
\begin{gathered}
y_{i}=\beta_{01}+\beta_{11} x_{1 i}+\cdots+\beta_{p 1} x_{1 i}^{p}+ \\
a_{11}\left(x_{i}-K_{j}\right)_{+}^{p} \ldots a_{m 1}\left(x_{1 i}-K_{m 1}\right)_{+}^{p}+\beta_{02}+ \\
\beta_{12} x_{2 i}+\cdots+\beta_{p 2} x_{2 i}{ }^{p}+a_{12}\left(x_{2 i}-K_{12}\right)_{+}^{p} \cdots+ \\
a_{m 2}\left(x_{2 i}-K_{m 2}\right)_{+}^{p}+\cdots+\beta_{0 q}+\beta_{1 q} x_{q i}+\cdots+ \\
\beta_{p q} x_{q i}^{p}+a_{1 q}\left(x_{q i}-K_{l q}\right)_{+}^{p}+\cdots+a_{m p}\left(x_{p i}-\right. \\
\left.K_{m p}\right)_{+}^{p}+\varepsilon_{i}
\end{gathered}
$$

\section{Estimator Spline}

Estimasi regresi spline dilakukan dengan metode Ordinary Lastt Square (OLS) atau sering juga di sebut dengan Metode Kuadrat Terkecil (MKT). Adapun persamaannya dapat dituliskan :

$$
\beta=\left(X^{\prime} X\right)^{-1} X^{\prime} y
$$

\section{Pemilihan Titik Knot Optimal}

Pemilihan knot merupakan bagian dari Regresi Spline yang sangat penting. Oleh karena itu agar diperoleh Spline yang optimal dipilih titik knot yang optimal. Metode yang sering digunakan untuk memilih titik knot optimal menurut Eubank (1988) salah satunya yaitu metode generalized cross validation $(G C V)$. [8] Cara menghitung $G C V$ dapat dilihat seperti berikut ini: 


$$
\begin{gathered}
G C V(k)=\frac{\operatorname{MSE}(k)}{\left.\left(n^{-1}\right) \operatorname{tr}[1-A(k)]\right)^{2}} \\
\text { Dengan } \operatorname{MSE}(k)=n^{-1} \sum_{i=1}^{n}\left(y_{1}-\right.
\end{gathered}
$$
$\hat{y})^{2}, n$ adalah Jumlah data, $I$ adalah matriks identitas, $k$ adalah titik knot $\left(k_{1}, k_{2}, k_{3}, \ldots, k_{n}\right), \operatorname{dan} A(k)=x\left(x^{\prime} x\right)^{-1} x^{\prime}$.

\section{Pengujian parameter model regresi Spline}

a. Uji Serentak (Simultan) secara serentak secara bersamaan terhadap model dengan hipotesisi dari pengujian adalah :

$\mathrm{H}_{0}: \beta_{0}=\beta_{1}=\beta_{2}=\cdots=\beta_{j}=0$

$\mathrm{H}_{1}$ : paling tidak ada satu $\beta_{j} \neq, j=$ $1,2, \ldots, p$

$$
\begin{gathered}
\text { Statistik uji } \\
F_{\text {hitung }}=\frac{M \text { MSRegresi }}{M S E r r o r} \\
\frac{\sum_{i=1}^{n}\left(\hat{y}_{1}-\bar{y}_{1}\right)^{2} / p}{\sum_{i=1}^{n}\left(y_{1}-\hat{y}_{1}\right)^{2} /(n-p-1)}
\end{gathered}
$$

Daerah penolakan : tolak $\mathrm{H}_{0}$ jika $F_{\text {hitung }}>$ $F_{\text {tabel }}\left(F_{\alpha} ;(k-1, n-k)\right.$ atau $p$-value $<$ $\alpha$

b. Uji Individu bertujuan untuk mengetahui seberapa jauh variabel prediktor secara individual dalam menerangkan variasi variabel respon. Hipotesis dari pengujian secara individu adalah sebagai berikut:

$\mathrm{H}_{0}: \beta_{k}=0$; artinya variabel prediktor tidak berpengaruh terhadap variabel respon.

$\mathrm{H}_{1}: \beta_{k} \neq 0 ; k=1,2, \ldots, p ;$ artinya variabel prediktor berpengaruh terhadap variabel respon.

\section{Statistik uji}

$$
t_{\text {hitung }}=\frac{\widehat{\beta}_{k}}{S E \widehat{\beta}_{k}}
$$

Daerah penolakan: $\mathrm{H}_{0}$ ditolak jika $\left|t_{\text {hitung }}\right|>t_{\operatorname{tabel}\left(\frac{\alpha}{2}, n-k\right)}$.

\section{Pengujian Asumsi Residual Model Regresi}

Pengujian asumsi residual dilakukan untuk mengetahui apakah residual yang dihasilkan telah memenuhi asumsi yakni identik, dan berdistribusi normal.

a. Pengujian asumsi residual identik

Uji asumsi identik digunakan untuk melihat homogenitas dari variansi residual.
Untuk mendeteksi adanya heteroskedastisitas menggunakan uji Glejser. Hipotesis yang digunakan adalah sebagai berikut.

$\mathrm{H}_{0}: \sigma_{1}^{2}=\sigma_{2}^{2}=\cdots=\sigma_{n}^{2}=\sigma^{2}$

$\mathrm{H}_{1}$ :Minimal ada satu $\sigma_{i}^{2}=\sigma^{2} ; i=$ $1,2, \ldots, n$

Statistik uji yang digunakan adalah sebagai berikut;

Fhitung $=\frac{\frac{\sum_{i=1}^{n}\left(\left|\widehat{e}_{i}\right|-|\bar{e}|\right)^{2}}{k-1}}{\frac{\sum_{i=1}^{n}\left(\left.\left|e_{i}\right||-| \widehat{e}_{i}\right|^{2}\right.}{n-k}}$

Daerah penolakan: tolak $\mathrm{H}_{0}$ jika $F_{\text {hiung }}>F_{\text {tabel }}(F F \alpha ;(k-1, n-k))$ atau $p$-value $<\alpha$. Nilai $s$ adalah banyaknya parameter model glejser.

b. Pengujian asumsi residual berdistribusi normal

Uji ini dilakukan untuk melihat residual mengikuti distribusi normal. Hipotesis yang digunakan untuk pengujian normalitas residual adalah sebagai berikut. $\mathrm{H}_{0}: F_{n}(\varepsilon)=F_{0}(\varepsilon)$ Residual mengikuti distribusi normal

$\mathrm{H}_{1}: F_{n} \neq F_{0}(\varepsilon)$ Residual tidak mengikuti distribusi normal

Statistik uji yang digunakan KolmogorovSmirnov adalah sebagai berikut;

$$
Z_{\text {hitung }}=\operatorname{Sup}_{x}\left|f_{n}(x)-f_{0}(x)\right|
$$

Daerah penolakan tolak $\mathrm{H}_{0}$ jika $Z_{\text {hitung }}>Z_{\alpha}$ atau $P$-Value $<\alpha$.[9]

\section{Koefisien Determininsi}

Koefisisen determinisi $\left(\mathrm{R}^{2}\right)$ adalah alat untuk mengukur proporsi keragaman atau variansi total disekitar nilai tengah y yang dapat dijelaskan oleh model regresi. Secara umum semakin besar nilai $\mathrm{R}^{2}$, maka semakin baik pula model yang didapatkan karena mampu menjelaskan lebih banyak data (Draper \& Smith, 1992). Rumus $\mathrm{R}^{2}$ dapat ditulis sebagai berikut:[10]

$$
\boldsymbol{R}^{2}=\frac{\sum\left(\hat{y}_{i}-\bar{y}\right)^{2}}{\sum\left(y_{i}-\bar{y}\right)^{2}} \times 100 \%
$$

\section{Indeks Pembangunan Manusia (IPM)}

Indeks pembangunan manusia (IPM) merupakan salah satu alat ukur yang digunakan 
untuk menilai kualitas pembangunan manusia, baik dari sisi dampaknya terhadap kondisi fisik manusia (kesehatan dan kesejahteraan) maupun yang bersifat non-fisik (pendidikan) pembangunan berdampak pada kondisi fisik masyarakat misalnya tercermin dalam angka harapan hidup serta kemampuan daya beli masyarakat, sedangkan dampak non-fisik dapat dilihat dari kualitas pendidikan masayarakat. Indeks pembangunan manusia (IPM) merupakan indikator tingkat pembangunan manusia suatu wilayah, yang dihitung memlalui perbandingan dari angka harapan hidup, pendidikan dan standar hidup layak. Untuk menjamin tercapainya tujuan pembangunan manusia, empat hal pokok yang perlu diperhatikan adalah produktivitas, pemerataan, keseinambungan, pemberdayaan (UNDP, 1995 dalam Shinegi, 2013)

\section{METODOLOGI}

Data yang digunakan dalam penelitian ini adalah data sekunder yang diperoleh dari Badan Pusat Statistik (BPS) Indonesia. Variabel respon yang digunakan pada penelitian ini adalah Indeks Pembangunan Manusia (IPM) dan variabelvariabel yang diduga berpengaruh didapatkan dari referensi penelitian sebelumnya. Variabel yang digunakan pada penelitian ini disajikan dalam Tabel 1 sebagai berikut:

Tabel 1 :Variabel Penelitian

\begin{tabular}{cl}
\hline Variabel & \multicolumn{1}{c}{ Keterangan } \\
$\mathrm{Y}$ & $\begin{array}{l}\text { Indeks Pembangunan Manusia } \\
(\text { IPM) }\end{array}$ \\
$\mathrm{X}_{1}$ & $\begin{array}{l}\text { Tingkat Partisispasi Angkatan } \\
\text { Kerja (TPAK) }\end{array}$ \\
$\mathrm{X}_{2}$ & Angka Partisipasi Murni (APM) \\
$\mathrm{X}_{3}$ & Kepadatan Penduduk \\
$\mathrm{X}_{4}$ & Fasilitas Kesehatan \\
$\mathrm{X}_{5}$ & $\begin{array}{l}\text { Produk Domestik Ragional Bruto } \\
\text { (PDRB) }\end{array}$ \\
\hline
\end{tabular}

\section{Teknik Analisis}

Adapun langkah-langkah analisis data yang dilakuakan dalam penelitian ini adalah sebagai berikut:

1. Membuat statistika deskriptif dari masingmasing variabel dan mengetahui karakteristik indeks pembangunan manusia (IPM) di Indonesia.

2. Membuat sceter plot antara indeks pembangunan manusia (IPM) (Y) dengan masing-masing variabel prediktor.

3. Memodelkan Indeks pembangunan manusia (IPM) di Indonesia dengan menggunakan Spline dengan beberapa titik knot yaitu titik knot satu, dua dan tiga titik knot.

4. Memilih titik knot optimal berdasarkan GCV minimum.

5. Memodelkan Indeks pembangunan manusia (IPM) dengan variabel prediktornya menggunakan spline dengan knot optimal.

6. Melakukan pengujian signifikansi parameter.

7. Membuat interpretasi dan kesimpulan.

\section{PEMBAHASAN}

\section{Hasil Penelitian}

Karakteristik Indeks Pembangunan Manusia (IPM) dan Faktor-faktor yang diduga berpengaruh di Indonesia tahun 2018

Untuk mengetahui gambaran secara umum karakteristik dari setiap indikator atau variabelvariabel yang digunakan maka ditampilkan statistika deskriptif berikut :

Tabel 2: Statistika Deskriptif

\begin{tabular}{ccccc}
\hline Peubah & Min & Max & Mean & Variance \\
\hline$Y$ & 60,06 & 80,47 & 70,386 & 15,953 \\
$X_{1}$ & 62,90 & 79,11 & 67,95 & 14,152 \\
$X_{2}$ & 44,31 & 73,00 & 61,74 & 37,140 \\
$X_{3}$ & 0,03 & 63,13 & 2,94 & 115,678 \\
$X_{4}$ & 0,350 & 13,540 & 2,936 & 11,154 \\
$X_{5}$ & 16,26 & 71,91 & 52,04 & 181,311 \\
\hline
\end{tabular}

Variabel Y merupakan variabel Indeks Pembangunan Manusia (IPM). Pada tabel 2 diketahui bahwa nilai tertinggi variabel IPM terdapat di provinsi DKI jakarta sedangkan terendah terdapat di provinsi Papua. Variabel $\mathrm{X}_{1}$ merupakan variabel Tingkat Partisipasi Angkatan Kerja, diketahui bahwa nilai tertinggi variabel Tingkat Partisipasi Angkatan Kerja terdapat diprovinsi Papua sedangkan terendah di provinsi Maluku. Variabel $\mathrm{X}_{2}$ merupakan variabel Angka Partisipasi Murni di mana diketahui nilai tertinggi variabel Angka Partisipasi Murni terdapat di provinsi Bali sedangkan terendah di provinsi Papua. Variabel 
$\mathrm{X}_{3}$ merupakan variabel Kepadatan Penduduk, diketahui nilai tertinggi variabel Kepadatan Penduduk berada di provinsi DKI Jakarta sedangkan terendah berada di provinsi Papua Barat. Variabel $\mathrm{X}_{4}$ Fasilitas Kesehatan, diketahui nilai tertinggi variabel Fasilitas Kesehatan terdapat di provinsi Jawa Timur sedangkan terendah berada di provinsi Kalimantan Utara. Variabel $\mathrm{X}_{5}$ merupakan variabel PDRB, diketahui nilai tertinggi variabel PDRB berada di provinsi Nusa Tenggara Timur sedangkan terendah berada di provinsi Kalimantan Timur.

Analisis Pola Hubungan Faktor-faktor yang Diduga Mempengaruhi Indeks Pemebangunan Manusia (IPM) di Indonesia Tahun 2018.

Salah satu langkah yang dilakukan dalam analisis regresi yaitu membuat scatter plot untuk mengetahui pola hubungan antara variabel prediktor dan variabel respon. Gambar 1 menunjukan pola hubungan yang terbentuk antara IPM dengan lima variabel dimana pola yang dihasilkan tidak membentuk suatu pola tertentu, sehingga estimasi model menggunakan regresi nonparametrik.
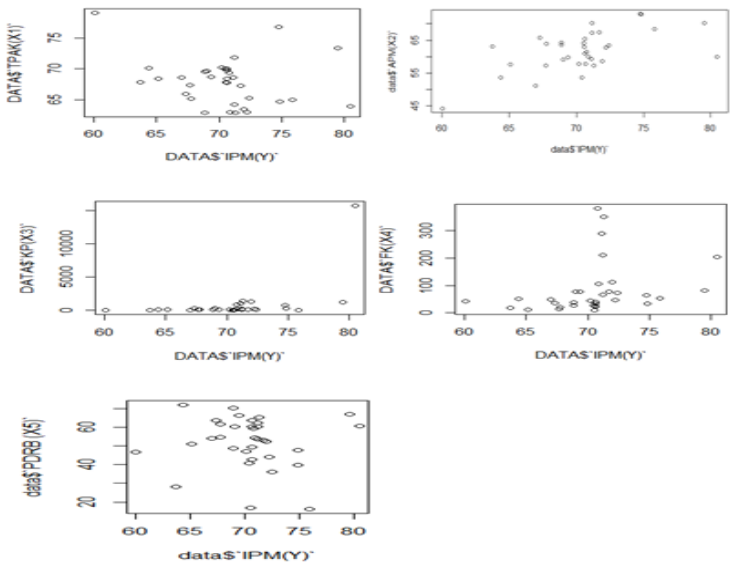

Gambar 1: ScatterPlot antara Indeks Pembangunan Manusia dengan 5 variabel yang diduga berpengaruh.

\section{Pemilihan Titik Knot Optimun}

Titik knot terbaik merupakan titik knot yang mempunyai nilai GCV minumum. Berikut perbandingan nilai GCV minimum diperoleh pada satu titik knot, dua titik knot hingga tiga titik knot yang ditunjukkan pada Tabel 3.

Tabel 3: Perbandingan Nilai GCV

\begin{tabular}{cc}
\hline Model & GCV \\
\hline 1 Titik Knot & 0.4076147 \\
2 Titik Knot & 0.3122641 \\
3 Titik Knot & 0.2564626 \\
\hline
\end{tabular}

Setelah enentukan titik knot dengan satu, dua hingga tiga titik knot diperoleh titik knot paling optimal dengan melihat GCV paling minimum. GCV paling minimum dihasilkan oleh model regresi nonparametrik Spline dengan tiga titik knot yaitu sebesar 0.2564626 . Oleh karena itu, diputuskan bahwa model terbaik yang akan dipilih adalah model dengan menggunakan tiga titik knot.

\section{Pengujian Signifikansi Peubah Model Regresi Nonparametrik Spline}

\section{Pengujian Simultan(Serentak)}

Pengujian secara simultan(serentak) dilakukan untuk melihat signifikansi parameter terhadap variabel respon secara keseluruhan dengan melibatkan seluruh variabel prediktor. Berikut tabel hasil uji Serentak.

Tabel 4. Hasil Uji Serentak Terhadap Model Regresi

\begin{tabular}{|c|c|c|c|c|c|}
\hline $\begin{array}{c}\text { Sumber } \\
\text { Variansi }\end{array}$ & $\begin{array}{c}\text { Derajat } \\
\text { Bebas } \\
(\mathrm{db})\end{array}$ & $\begin{array}{c}\text { Jumlah } \\
\text { Kuadrat } \\
(\mathrm{JK})\end{array}$ & $\begin{array}{c}\text { Rataan } \\
\text { Jumlah } \\
\text { Kuadrat } \\
(\mathrm{RJK})\end{array}$ & F_hitung & P_Value \\
\hline Regression & 20 & 29,85896 & 1.492948 & 6,178946 & 0.00081240 \\
\hline Error & 13 & 3,141041 & 0.2416185 & & \\
\hline Total & 33 & 33 & & & \\
\hline
\end{tabular}

Berdasarkan hasil ANOVA (Analysis of Variance) pada Tabel 4 diketahui bahwa statistik uji menggunakan $F_{\text {hitung }}$ sebesar 6,178946 dengan $P_{\text {_Value }}$ sebesar 0.00081240. pada tingkat signifikansi $(\alpha) 5 \%$. Nilai $P_{-}$Value lebih kecil dari $\alpha$ sehingga didapatkan keputusan tolak $\mathrm{H}_{0}$. Kesimpulan yang diperoleh yaitu minimal terdapat satu parameter yang signifikan terhadap nilai Indeks Pembangunan Manusia (IPM) di Indonesia. 


\section{Pengujian Individu}

Uji individu ini dilakukan untuk mengetahui parameter mana saja yang berpengaruh secara signifikan terhadap model. Berikut ini adalah hasil pengujian signifikansi parameter model secara individu.

Tabel 5. Estimasi Parameter

\begin{tabular}{|c|c|c|c|}
\hline Var & $\begin{array}{c}\text { Param } \\
\text { eter }\end{array}$ & P_Value & Keputusan \\
\hline & $\beta_{0}$ & 0.7848466 & Tidak Signifikan \\
\hline \multirow{6}{*}{$x_{1}$} & $\beta_{1}$ & 0.131 & Tidak Signifikan \\
\hline & $\beta_{2}$ & 0.094 & Tidak Signifikan \\
\hline & & 18554 & \\
\hline & $\beta_{3}$ & 0.085 & Tidak Signifikan \\
\hline & & 0848 & \\
\hline & $\beta_{4}$ & $\begin{array}{l}0.200 \\
8209\end{array}$ & Tidak Signifikan \\
\hline \multirow{4}{*}{$x_{2}$} & $\beta_{5}$ & $\begin{array}{c}0.577 \\
9019\end{array}$ & Tidak Signifikan \\
\hline & $\beta_{6}$ & $\begin{array}{l}0.844 \\
6671\end{array}$ & Tidak Signifikan \\
\hline & $\beta_{7}$ & $7523^{0.600}$ & Tidak Signifikan \\
\hline & $\beta_{8}$ & $\begin{array}{l}0.895 \\
8354\end{array}$ & Tidak Signifikan \\
\hline \multirow{4}{*}{$x_{3}$} & $\beta_{9}$ & $\begin{array}{c}0.913 \\
9235\end{array}$ & Tidak Signifikan \\
\hline & $\beta_{10}$ & $866^{0.913}$ & Tidak Signifikan \\
\hline & $\beta_{11}$ & $\begin{array}{c}0.262 \\
7427\end{array}$ & Tidak Signifikan \\
\hline & $\beta_{12}$ & $\begin{array}{r}0.070 \\
44297\end{array}$ & Tidak Signifikan \\
\hline \multirow{4}{*}{$x_{4}$} & $\beta_{13}$ & $\begin{array}{c}0.088 \\
10609\end{array}$ & Tidak Signifikan \\
\hline & $\beta_{14}$ & $\begin{array}{c}0.014 \\
40176\end{array}$ & Signifikan \\
\hline & $\beta_{15}$ & $\begin{array}{c}0.006 \\
007549\end{array}$ & Signifikan \\
\hline & $\beta_{16}$ & $\begin{array}{c}0.072 \\
99387\end{array}$ & Tidak Signifikan \\
\hline \multirow[t]{4}{*}{$x_{5}$} & $\beta_{17}$ & $\begin{array}{c}0.263 \\
8096\end{array}$ & Tidak Signifikan \\
\hline & $\beta_{18}$ & $\begin{array}{l}0.300 \\
5901\end{array}$ & Tidak Signifikan \\
\hline & $\beta_{19}$ & $\begin{array}{c}0.267 \\
4479\end{array}$ & Tidak Signifikan \\
\hline & $\beta_{20}$ & $354^{0.354}$ & Tidak Signifikan \\
\hline
\end{tabular}

\section{in} lambil adalah gagal tolak $\mathrm{H}_{0}$. Hal ini memberika $\mathrm{n}$ kesimpulan Residual yang dihasilkan model $\mathrm{m}$ emenuhi asumsi identik atau tidak terjadi kasus heteroskedastisitas. 


\section{Pengujian asumsi residual berdistribusi normal}

Uji normalitas digunakan untuk mengetahui apakah residual telah mengikuti pola distribusi normal. Pengujian normalitas yang digunakan menggunakan uji KolmogorovSmirnov. Adapun Normal Probability Plot Residual yang dihasilkan ditunjukkan pada gambar berikut.

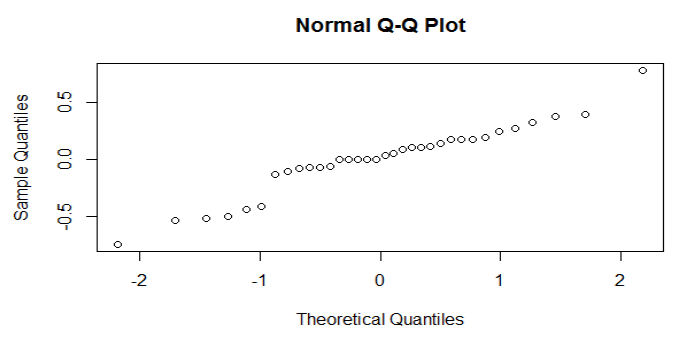

Gambar 2 Normal Probability Plot Residual

Berdasarkan Gambar 2 diperoleh $P_{-}$Value 0,07179 dengan taraf signifikansi $(\alpha)=0.05 \mathrm{seh}$ ingga keputusan uji Kolmogorov -Smirnov mem berikan keputusan gagal tolak $\mathrm{H}_{0}$ karena $P_{-}$Valu $e>\alpha$ yang artinya bahwa residual mengikuti dist ribusi normal atau asumsi residual normal telah terpenuhi

\section{Koefisien Determininsi}

Nilai koefisien Determinisi $\left(R^{2}\right)$ yang menunjukkan sebesara besar kebaikan model regresi dalam menjelaskan varibilitas angka Indeks Pembanguanan Manusia (IPM) di Indonesia. Berdasarkan Perhitungan didapatkan nilai $R^{2}$ sebesar $90,48 \%$. Itu artinya variabel Fasilitas Kesehatan mampu menjelaskan variabilitas angka Indeks Pembangunan Manusia (IPM) di Indonesia sebesar 90,48\%. Dilihat dari nilai $R^{2}$ yang diperoleh dapat disimpulkan bahwa model regresi nonparametrik Spline yang dihasilkan merupakan model yang baik.

\section{Interpretasi Model Regresi Nonparametrik Spline}

Setelah dilakukan pengujian model regresi nonparemtrik Spline dan semua asumsi residual terpenuhi, maka model regresi yang telah diperoleh tersebut dapat diinterpretasikan.

$$
\begin{aligned}
\hat{y}=-21,6404304 & X_{4} \\
& -52,2597400\left(X_{4}+0,4878535\right) \\
& -40,6379410\left(X_{4}\right. \\
& -\quad 0,03181247) \\
& +9,8927462\left(X_{4}-0,11241030\right)
\end{aligned}
$$

Apabila diasumsikan variabel lain konstan, maka pengaruh Fasilitas Kesehatan $\left(X_{4}\right)$ terhadap Indeks Pembangunan Manusia adalah

$$
\hat{y}=\left\{\begin{array}{cc}
-21,6404304 \mathrm{X}_{4}, & x_{4}<-0,4878535 \\
25,4950970-73,9001740 \mathrm{X}_{4}, & -0,4878535 \leq x_{4}<0,03181247 \\
26,7878903-114,538114 X_{4}, & 0,03181247 \leq x_{4}<0,11241030 \\
25,6758437-104,6453652 X_{4}, & X_{4} \geq 0,11241030
\end{array}\right.
$$

Pada persamaan tersebut terdapat empat interval untuk masing-masing potongan spline. Potongan-potongan persamaan di atas dapat disajikan dalam bentuk gambar sebagai berikut;

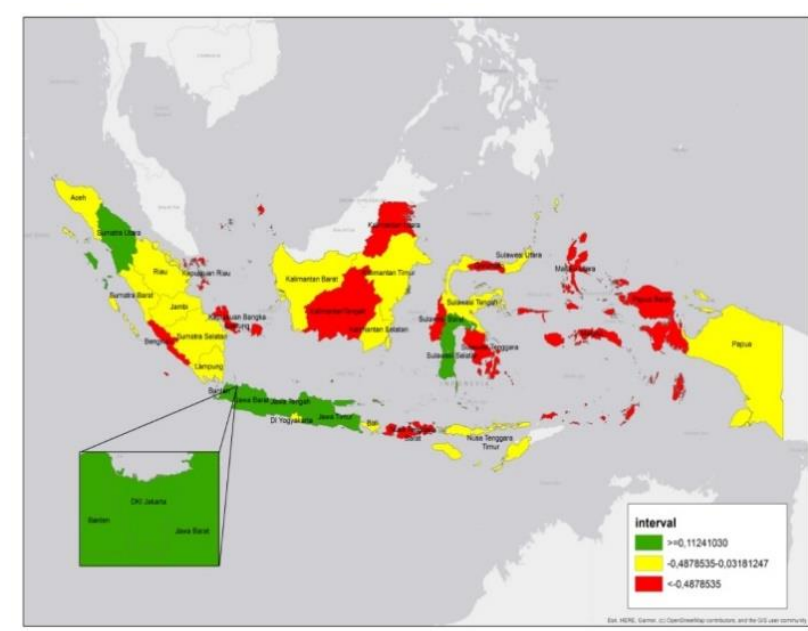

Gambar 2: Peta Indonesia Berdasarkan Potongan Persamaan $\mathrm{X}_{4}$

Berdasarkan model tersebut, apabila wilayah dengan Fasilitas Kesehatanhtn e kurang dari $0,4878535 \%$ nnaik sebesar satu $\%$, maka nilai IPM cenderung turun sebesar -21,640430\% wilayah yang termasuk dalam kategori ini yaitu Provinsi Bengkulu, Kepulauan Bangka Belitung, Kepulauan Riau, Nusa Tenggara Barat, Kalimantan Tengah, Kalimantan Utara, Sulawesi Tenggara, Gorontalo, Sulawesi Barat, Maluku, maluku Uatara dan Papua Barat. Selanjutnya pada interval kedua, apabila Fasilitas Kesehatan berkisar antara -0,4878535 hingga 0,03181\% naik sebesar satu \% maka IPM cenderung turun sebesar 5,833167\% maka wilayah yang termasuk kategori ini yaitu Provinsi Aceh, 
Sumatra Barat, Riau, Jambi, Sumatra Selatan, Lampung, Di Yogyakarta, Bali, Nusa Tenggara Barat, Kalimantan Barat, Kalimantan Selatan, Kalimantan Timur, Sulawesi Utara dan Sulawesi Tengah. Kemudian pada interval ketiga apabila Fasilitas Kesehatan berkisar antara 0,03181247 hingga $0,11241030 \%$ naik sebesar satu $\%$, maka IPM cenderung turun sebesar 114,538114\% dan tidak ada wilayah yang termasuk dalam kategori ini. Pada interval yang terakhir apabila Fasilitas Kesehatan lebih besar dari 0,011241030\% naik sebesar satu \% maka IPM cenderung turun sebesar -104,6453652 dan wilayah yang termasuk ndalam kategori ini yaitu Sumatra Utara, DKI Jakarta, Jawa Barat, Jawa Tengah, Jawa Timur, Banten dan Sulawesi Selatan.

\section{KESIMPULAN}

Model spline terbaik untuk pemodelan Indeks Pembangunan Manusia (IPM) di Indonesia dengan menggunakan tiga titik knot. Dimana diperoleh 1 variabel yang berpengaruh secara signifikan terhadap Indeks Pembangunan Manusia (IPM) yaitu variabel Fasilitas Kesehatan dengan nilai koefisien determininsi $\left(\mathrm{R}^{2}\right)$ sebesar 90,48\%. Hal ini menunjukkan bahwa model tersebut mampu menjelaskan keragaman nilai IPM di Indonesia sebesar $90,84 \%$ sedangkan sisanya dijelaskan oleh variabel lain.

\section{DAFTAR PUSTAKA}

[1] Statistik, B. P. (2014). Indeks pembangunan manusia. Tersedia pada http://www. bps. go. id/menutab. php.

[2] Putra, I. M. B., Srinadi, I. G. A. M., \& Sumarjaya, I. W. (2015). Pemodelan Regresi Spline. E-Journal Matematika, 4(3), 110-114.

[3] Härdle, W. (1990). Applied nonparametric regression (No. 19). Cambridge university press.

[4] Suyono, M. S. (2015). Analisis Regresi untuk Penelitian. Deepublish.

[5] Yudiaatmaja, F. (2013). Analisis Regresi Dengan Menggunakan Aplikasi Komputer Statistik. Gramedia Pustaka Utama.

[6] Fajriyyah, N., \& Budiantara, I. N. (2015). Pemodelan indeks pembangunan gender dengan pendekatan regresi nonparametrik spline di Indonesia. Jurnal Sains Dan Seni ITS, 4(2), 2337-3520.

[7] Hidayat, R., Yuliani, Y., \& Sam, M. (2018). MODEL REGRESI NONPARAMETRIK DENGAN PENDEKATAN SPLINE TRUNCATED. Prosiding, 3(1).

[8] Amalia, M. R. (2017). MODEL REGRESI NONPARAMETRIK

TRUNCATED PADA PRODUK DOMESTIK REGIONAL BRUTO TERHADAP INVESTASI DI KABUPATEN TUBAN.

[9] Muhgni, M., Fadly, F., Adnan, A., \& Harison, H. (2020). Pemodelan Tingkat Pengangguran Terbuka di Pulau Sumatera Dengan Menggunakan Regresi Nonparametrik Spline. Jurnal Sains Matematika dan Statistika, 6(1).

[10] Merdekawati, I. P., \& Budiantara, I. N. (2013). Pemodelan Regresi Spline Truncated Multivariabel pada FaktorFaktor yang Mempengaruhi Kemiskinan di Kabupaten/Kota Provinsi Jawa Tengah. Jurnal Sains dan Seni ITS, 2(1), D19-D24. 